\begin{tabular}{cc|c}
\hline Tar. Bil. Der. & Journal of Agricultural Sciences \\
& $\begin{array}{c}\text { Dergi web sayfası: } \\
\text { www.agri.ankara.edu.tr/dergi }\end{array}$ & Journal homepage: \\
& www.agri.ankara.edu.tr/journal
\end{tabular}

\title{
Effects of Tribulus terrestris (Puncture Vine) Supplementation on Performance and Digestive System of Broiler Chicks
}

\author{
Ahmet ŞAHIN ${ }^{\mathrm{a}}$, Metin DURU ${ }^{\mathrm{a}}$ \\ a Mustafa Kemal University, Faculty of Agriculture, Department of Animal Science, Antakya-Hatay, TURKEY
}

\section{ARTICLE INFO}

Research Article - Animal Production

DOI: 10.1501/Tarimbil_0000001147

Corresponding author: Ahmet ŞAHIN, e-mail: asahinmkuagri@gmail.com, Tel: +90(326) 2455845

Received: 02 August 2009, Received in revised form: 16 January 2011, Accepted: 08 February 2011

\begin{abstract}
The purpose of this study was to determine the possible effects of the herbal preparation Tribulus terrestris (TT) extract on muscle building (increase in breast and legs weight) in broiler chicks. One hundred eighty broiler chicks were assigned to three treatment groups; control, $180 \mathrm{ppm}$ TT and $360 \mathrm{ppm}$ TT extract. Body weight, body gain and dietary intake were determined weekly for 6 weeks. Control diet included $234 \mathrm{~g}$ crude protein $(\mathrm{CP})$ and $3141 \mathrm{kcal}$ ME (grower) per kg diet during 1-21 days of age and $204 \mathrm{~g} \mathrm{CP}$ with $3199 \mathrm{kcal} \mathrm{ME}$ (finisher) per kg diet for 22-42 days of age. Growth performance, muscle building (increase in breast and legs weights) and digestive system parts were determined. TT extract did not affect growth performance and muscle building but decreased ileum + jejunum and empty gut weights $(P<0.05)$. In conclusion, the present results showed that Tribulus terrestris had no effect on growth or muscle building. This may be TT extract do not work in birds as do in human subjects, and more likely, the physiological differences between human and bird.
\end{abstract}

Keywords: Tribulus terrestris; Puncture vine; Muscle growth; Broiler chicks; Digestive system

\section{Tribulus terrestris (Demir Dikeni) İlavesinin Etlik Civcivlerde Performans ve Sindirim Sistemi Üzerine Etkisi}

\section{ESER BİLGİSi}

Araştırma Makalesi - Hayvansal Üretim

Sorumlu Yazar: Ahmet ŞAHIN, e-posta: asahinmkuagri@gmail.com, Tel: +90(326) 2455845

Geliş tarihi: 02 Ağustos 2009, Düzeltmelerin gelişi: 16 Ocak 2011, Kabul: 08 Şubat 2011

\section{ÖZET}

Bu çalışmada, Tribulus terrestris (TT) bitki ekstraktının etlik civcivlerde kas yapıcı (göğüs ve but ağırlığında artış) etkisinin belirlenmesi amaçlanmıştır. 180 adet etlik civciv kontrol, $180 \mathrm{ppm}$ ve $360 \mathrm{ppm}$ olmak üzere 3 gruba ayrılmışır. Canlı ağırlık, canlı ağırlık kazancı ve yem tüketimi 6 hafta boyunca haftalık olarak tespit edilmiştir. Kontrol yemi kg başına 1-21 günlük yaşlar için $234 \mathrm{~g}$ ham protein, $3141 \mathrm{kcal} \mathrm{ME,} \mathrm{22-42} \mathrm{günlük} \mathrm{yaşlarda} 204 \mathrm{~g}$ ham protein, 3199 kcal ME içermiştir. Büyüme performansı, kas gelişimi (göğüs ve but ağırlığında artış) ve sindirim sistemi parçaları belirlenmiştir. TT büyüme performansına ve kas gelişimine etki etmemiş fakat ileum+jejunum ve boş sindirim sistemi ağırlığını düşürmüştür $(P<0.05)$. Sonuç olarak Tribulus terrestris, büyümeye ve kas gelişimine etkili olmamıştır. Bu durum, TT ekstraktının kanatlı hayvanlarda insanlardaki gibi çalışmaması ve bu da insan ve kuşların fizyolojilerinin birbirlerinden farklı olmaları ile açıklanabilir.

Anahtar sözcükler : Tribulus terrestris; Demir dikeni; Kas gelişimi; Etlik civciv; Sindirim sistemi 


\section{Giriş}

Tribulus terrestris (TT) is an industrial source for production of medicinal preparations based on its saponin fraction. Food supplements with a claim of general stimulating action are also currently on sale in Europe and USA (Kostova \& Dinchev 2005).

Tribulus terrestris L. (Zygophyllaceae), usually called "demir dikeni" in Turkey, is an annual herb that is widely distributed in Turkey, China, Japan, Korea, the western part of Asia, the southern part of Europe and Africa. It is popularly claimed to improve sexual function possibly through increase in the free serum testosterone (Brown et al 2001). This plant is extremely rich in substances having potential biological significance such as saponins, flavonoids, alkaloids (Wang et al 1997; Sun et al 2002), glycosides, phytosteroids (Wu et al 1996) and other constituents (Wu et al 1999). Although the furostanol saponins (Combarieu et al 2003; Conrad et al 2004) are the main components of TT of Bulgarian origin, only methylprotodioscin, protodioscin, methylprototribestin and prototribestin have been isolated and identified so far (Kostova et al 2002).

In humans, it has been used to increase testosterone levels and improve muscle (Adimoelja \& Adaikan 1997; Gauthaman et al 2002; Adaikan et al 2000). Protodioscin, the most dominant saponin in TT, is the main substance responsible for increasing testosterone (Ganzera et al 2001) and its derivatives (Adimoelja \& Adaikan 1997; Gauthaman et al 2000). Protodioscin has, also, been found to increase the levels of dehydroepiandrosterone (Adimoelja \& Adaikan 1997), dihydrotestosterone and dehydroepiandrosterone sulphate (Gauthaman et al 2000). Gauthaman \& Adaikan (2008) investigated the hormonal effects of TT in rabbit and rat. Rabbits and normal rats were treated with $2.5,5$ and $10 \mathrm{mg} \mathrm{kg}^{-1}$ of TT extract orally for 8 weeks, for their chronic study. In addition, castrated rats were treated either with testosterone cypionate $(10 \mathrm{mg}$ $\mathrm{kg}^{-1}$, subcutaneously; biweekly for 8 weeks) or TT orally ( $5 \mathrm{mg} \mathrm{kg}$ daily $^{-1}$ for 8 weeks). In rabbits, both testosterone and dihydrotestosterone were increased compared to control, however, only the increases in dihydrotestosterone (by 30and $32 \%$ at 5 and $10 \mathrm{mg}$ $\mathrm{kg}^{-1}$ ) were statistically significant. In castrated rats, increases in testosterone levels by $51 \%$ and $25 \%$ were observed with testosterone cypionate and TT extract respectively that were statistically significant. TT increases some of the sex hormones, possibly due to the presence of protodioscin in the extract. The testosterone precursors enhance testosterone production because they are one small biochemical step away from testosterone and help elevate testosterone through anabolic steroid effects. TT has an effect on even females. Geyer et al (2000) detected the anabolic-androgenic steroids 4-androstene-3,17-dion, 4-androstene-3ß,17ß-diol, 5-androstene-3ß,17ß-diol, 19-nor-4-androstene3,17-dion and 19-nor-4-androstene-3ß,17ß-diol in TT extract and found out that the urinary concentrations of norandrosterone was between 4 and $623 \mathrm{ng} \mathrm{m} l^{-1}$ by 3-4 hours after administration of TT. A female volunteer additionally showed an increase in the ratio testosterone/epitestosterone from 0.6 to 4.2 .

The active agent in TT is believed to be protodioscin. Protodioscin is a precursor to dehydroepiandrosterone (DHEA). As you may know, DHEA and androstenedione are precursors to testosterone. As one ages, androgen levels decline. Therefore, DHEA and androstenedione supplementation have been theorized as a means of naturally increasing testoserone levels particularly in older individuals. Although TT is a precursor to DHEA, TT is believed to indirectly affect testosterone levels by stimulating the release of leutinizing hormone ( $\mathrm{LH})$. $\mathrm{LH}$ serves to stimulate the natural production of testosterone. Theoretically, moderately increasing testosterone availability during training may promote greater gains in strength and muscle mass (Kreider 2001).

Sahin \& Forbes (1997) studied dehydroepiandrosterone in broiler chicks to alleviate the effect of corticosterone administration and found out that dehydroepiandrosterone tended to increase muscle mass in broiler chicks. Çek et al (2007) examined the effects of TT on growth acceleration in the Convict Cichlid Cichlasoma nigrofasciatum. A $0.30 \mathrm{~g}$ TT extract in one $l$ water significantly improved the growth rate of $C$. nigrofasciatum. 
However, there is a limited study whether TT extract affects growth rate and body muscle (increase in breast and legs weight) in broiler chicks since these body parts are of significant economical importance on broiler meat production. More recently, Duru (2005) used TT extract (60 and 120 $\mathrm{ppm}$ ) by giving broiler chicks orally in commercial diet for 21 days. TT extract did not affect growth performance and body parts. This result encouraged us to test the efficacy of TT extract in higher doses (180 and $360 \mathrm{ppm}$ in basal diets) on growth and muscle building in broiler chicks.

\section{Material and Methods}

At the beginning of experiment, one-day old 180 broiler chicks (Ross 308) were individually weighed and allocated into experimental groups of equal mean body weight $(51.5 \pm 4.16 \mathrm{~g}$, one day after chicks arrived to experimental unit from hatchery) according to the following experimental design for 42 days. Experimental birds were equally divided into three treatment groups; 60 birds (27 + , $\left.33 \mathrm{O}^{7}\right)$ were control (0 ppm Tribulus terrestris extract, TT), 60 birds (36,+ 24 §) were given 180 ppm TT extract and 60 birds (28 $\left.9,32{ }^{\top}\right)$ were 360 ppm TT extract in their diet. Treatment birds were divided into three sub-groups to make replication groups each included 20 birds. TT extract (origin: bulgarian) were purchased from Gym Spor Sağllk \& Gıda San. Tic. Ltd. Şti. in Istanbul. Powder of TT extract in commercial capsule poured and mixed carefully into basal diet. Experimental diets were mainly based on corn and soya bean. Control diet included $234 \mathrm{~g} \mathrm{CP}$ and $3141 \mathrm{kcal} \mathrm{ME}$ (grower) per $\mathrm{kg}$ diet for 1-21 days of age and $204 \mathrm{~g} \mathrm{CP}$ with $3199 \mathrm{kcal}$ ME (finisher) per $\mathrm{kg}$ diet for 22-42 days of age (Table 1). Both control and treatment diets did not include any antibiotics. Water was available throughout the experimental period. The experimental chicks were kept in floor pens $(1.4 \mathrm{~m}$ $\times 1.4 \mathrm{~m}$ ) in a poultry room with continuous $24 \mathrm{~h}$ day light and $18-24^{\circ} \mathrm{C}$ (a gradual decrease from $33^{\circ} \mathrm{C}$ from day old age) ambient temperature. The growth of chicks was monitored by weighing on weekly basis. Feed conversion ratio (g feed: g gain) were calculated for each replication during the experimental period. At the end of experiment when experimental birds were 42-d old, they (5 오 and $5 \hat{\delta}$ for each treatment) were slaughtered humanly for determination of body components and digestive system parts.

Data concerning growth performance, body components and digestive parts were analysed using the GLM procedure of SPSS (Windows version of SPSS, release 10.01) with Duncan's Multiple Range Test used to identify the significant differences between the respective means. Results are presented as means per bird with standard error of means (SEM).

\section{Results and Discussion}

The results regarding growth performance, body components and digestive system of broiler chicks are given in Table $2,3 \& 4$, respectively. TT extract did not affect feed intake, daily gain and feed efficiency during experimental period.

According to Table 3, breast, legs, feather, heart and abdominal fat pad weights were not affected by TT treatment although males had heavier body components than females. Also, liver weight was decreased by $360 \mathrm{ppm}$ TT treatment $(P=0.05)$ in both male and female chicks.

According to Table 4, intestine (duodenum, ileum + jejunum) weight was decreased by TT extract $(P<0.05)$ and this reflected to a decrease in empty gut weight $(P<0.05)$. In generally, TT extract decreased digestive morphology even though some parts (crop, proventriculus, gizzard, pancreas, ceca and colon) were not affected significantly.

It was expected in the current study that TT extract may increase blood testosterone level and, consequently, increase growth rate with the weights of body parts such as but this was not happen. In contrast, Gauthaman et al (2002) found out that the TT extract increased testosterone levels in rats. Çek et al (2007) found that the growth rate of fish treated with TT was found to be faster than that of the controls. The effects of the TT extract on body weight have been studied by Dimitrov et al (1987) in immature sheep and by Gauthaman et al (2002) in rats. Both authors found an increase in body weight, sexual activity and spermatogenesis. However, the present results in broiler chicks are 
Table 1-Composition of experimental basal diets for broilers (air-dry basis)

Çizelge 1-Denemede kullanılan etlik civciv bazal yemlerinin yapısı (havada-kuru esasta)

\begin{tabular}{|c|c|c|}
\hline Feed ingredients, $\%$ & $\begin{array}{c}\text { Grower } \\
\left(1^{s t}-21^{\text {st }} \text { days }\right)\end{array}$ & $\begin{array}{c}\text { Finisher } \\
\left(22^{\text {nd }}-41^{s t} \text { days }\right)\end{array}$ \\
\hline$\overline{\text { Corn }}$ & 48.0 & 53.0 \\
\hline Full fat soya & 32.0 & 26.0 \\
\hline Soybean meal & 5.0 & 5.0 \\
\hline Corn gluten meal & 8.0 & 5.0 \\
\hline Wheat bran & 1.3 & 6.0 \\
\hline Vegetable oil & - & 1.0 \\
\hline DCP \& Limestone & $2.5 \& 1.5$ & $2.0 \& 0.8$ \\
\hline Methionine \& Lysine & $0.3 \& 0.5$ & $0.2 \& 0.3$ \\
\hline $\mathrm{NaHCO}_{3} \& \mathrm{NaCl}$ & $0.3 \& 0.2$ & $0.3 \& 0.1$ \\
\hline Mineral and vitamin premix ${ }^{1}$ & 0.4 & 0.3 \\
\hline \multicolumn{3}{|l|}{ Calculated composition } \\
\hline ME, kcal kg ${ }^{-1}$ & 3141 & 3199 \\
\hline Crude protein, $\%$ & 23.4 & 20.4 \\
\hline Lysine, \% & 1.46 & 1.18 \\
\hline Methionine + systine, $\%$ & 1.09 & 0.90 \\
\hline $\mathrm{Ca}, \%$ & 1.28 & 0.88 \\
\hline $\mathrm{P}$ (available), \% & 0.51 & 0.42 \\
\hline
\end{tabular}

Table 2-Effects of Tribulus terrestris (TT) extract on body weight feed intake and feed conversion ratio (FCR) of broiler chicks

Çizelge 2-Etlik civcivlerde TT ekstraktının canlı ağırlık, yem tüketimi ve yem dönüşüm oranına etkileri

\begin{tabular}{|c|c|c|c|c|c|}
\hline Parameters $\left(\right.$ g bird $\left.^{-I}\right)$ & Control & $180 T T$ & $360 T T$ & SEM & $P$ values \\
\hline \multicolumn{6}{|l|}{$1-21 \mathrm{~d}$} \\
\hline$\overline{\text { Body weight at } 21 \mathrm{~d}}$ & 749.8 & 731.7 & 742.7 & 9.88 & 0.75 \\
\hline Feed intake & $1045.1^{\mathrm{a}}$ & $977.9^{b}$ & $1058.7^{\mathbf{a}}$ & 15.21 & 0.03 \\
\hline Body weight gain & 697.2 & 680.3 & 692.3 & 7.95 & 0.73 \\
\hline FCR (g feed: g gain) & 1.50 & 1.44 & 1.53 & 0.02 & 0.30 \\
\hline \multicolumn{6}{|l|}{$22-42 \mathrm{~d}$} \\
\hline Feed intake & 3308.9 & 3256.2 & 3322.4 & 52.45 & 0.89 \\
\hline Body weight gain & 1787.2 & 1849.3 & 1847.5 & 30.27 & 0.67 \\
\hline FCR (g feed: g gain) & 1.86 & 1.76 & 1.80 & 0.03 & 0.56 \\
\hline \multicolumn{6}{|l|}{$1-42 \mathrm{~d}$} \\
\hline 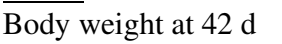 & 2537.0 & 2581.0 & 2590.2 & 24.76 & 0.64 \\
\hline Feed intake & 4354.1 & 4234.1 & 4381.1 & 63.45 & 0.67 \\
\hline Body weight gain & 2484.4 & 2529.6 & 2539.8 & 26.52 & 0.72 \\
\hline FCR (g feed: g gain) & 1.75 & 1.67 & 1.72 & 0.02 & 0.40 \\
\hline
\end{tabular}

Control: no Tribulus terrestris extract, 180TT: 180 ppm Tribulus terrestris extract, 360TT:360 ppm Tribulus terrestris extract

not similar to the previous findings in different species. Method of extraction may play an important role in testosteronic effects of TT.

In the present study, TT extract in mash form were used and administrated orally in food. When ingested, TT might have been solved in digestive system since it is soluble in water (Pandian \& Sheela 1995). Before being absorbed, testosteronic compounds, more likely, diminished by bird's digestive system in current dietary supplementation.

The present finding regarding digestive organ weights showed that TT decreased intestine weight significantly. It may have caused poor feed efficiency in treatment birds, but this was not happened. Despite of having shorter digestive system, TT birds utilised food efficiently as much 
Table 3-Effects of Tribulus terrestris (TT) extract on body components of broiler chicks

Çizelge 3-Etlik civcivlerde TT ekstraktının vücut parametreleri üzerine etkileri

\begin{tabular}{|c|c|c|c|c|c|c|c|c|c|c|}
\hline \multirow[b]{2}{*}{ Parameters } & \multicolumn{3}{|c|}{ Female } & \multicolumn{3}{|c|}{ Male } & \multirow[b]{2}{*}{ SEM } & \multicolumn{3}{|c|}{$P$ values } \\
\hline & Control & $180 T T$ & $360 T T$ & Control & $180 T T$ & $360 T T$ & & $T T$ & Sex & $T T x \operatorname{Sex}$ \\
\hline $\begin{array}{l}\text { Slaughter } \\
\text { weight }\end{array}$ & 2457.2 & 2445.6 & 2379.2 & 2808.8 & 2697.2 & 2736.8 & 36.76 & 0.36 & 0.00 & 0.56 \\
\hline Carcass, g & $1865.2^{\mathrm{a}}$ & $1816.0^{\mathbf{a b}}$ & $1750.4^{\mathbf{b}}$ & $2098.4^{\mathbf{A}}$ & $2009.6^{\mathbf{A B}}$ & $1989.2^{\mathbf{B}}$ & 26.95 & 0.03 & 0.00 & 0.82 \\
\hline $\begin{array}{l}\text { Carcass } \\
\text { yield, } \%\end{array}$ & $75.9^{\mathrm{a}}$ & $74.3^{\mathbf{b}}$ & $73.6^{\mathrm{b}}$ & $74.7^{\mathbf{A}}$ & $74.5^{\mathrm{AB}}$ & $72.7^{\mathbf{B}}$ & 0.28 & 0.003 & 0.02 & 0.48 \\
\hline Breast, g & 552.8 & 608.0 & 554.8 & 655.2 & 674.0 & 655.6 & 0.11 & 0.07 & 0.00 & 0.51 \\
\hline Breast, \% & $22.49^{c}$ & $24.87^{\mathrm{a}}$ & $23.31^{\mathbf{b}}$ & $23.30^{\mathbf{B}}$ & $24.98^{\mathbf{A}}$ & $23.95^{\mathbf{A B}}$ & 0.19 & 0.00 & 0.03 & 0.45 \\
\hline Legs, g & 506.0 & 508.8 & 516.4 & 576.4 & 588.0 & 617.6 & 9.97 & 0.25 & 0.00 & 0.60 \\
\hline Legs, \% & $20.58^{b}$ & $20.78^{\mathbf{b}}$ & $21.69^{a}$ & $20.54^{\text {B }}$ & $21.81^{\mathbf{A}}$ & $22.55^{\mathrm{A}}$ & 0.19 & 0.00 & 0.03 & 0.25 \\
\hline Feather, $g$ & 236.8 & 254.4 & 236.8 & 282.4 & 286.0 & 330.8 & 8.12 & 0.26 & 0.00 & 0.09 \\
\hline Feather, \% & 9.64 & 10.40 & 9.90 & $9.99^{\mathbf{B}}$ & $10.6^{\mathbf{A B}}$ & $12.10^{\mathbf{A}}$ & 0.21 & 0.03 & 0.01 & 0.04 \\
\hline Liver, $\mathrm{g}$ & $47.6^{\mathrm{a}}$ & $47.6^{\mathrm{a}}$ & $42.4^{b}$ & $54.4^{\mathrm{A}}$ & $52.8^{\mathbf{A}}$ & $50.0^{\mathbf{B}}$ & 0.88 & 0.003 & 0.00 & 0.66 \\
\hline Liver, \% & $1.94^{\mathrm{a}}$ & $1.95^{\mathrm{a}}$ & $1.78^{\mathrm{b}}$ & $1.94^{\mathrm{B}}$ & $1.96^{\mathbf{A}}$ & $1.82^{\mathbf{A}}$ & 0.02 & 0.00 & 0.46 & 0.78 \\
\hline Heart, $\mathrm{g}$ & 14.0 & 13.2 & 10.8 & 16.0 & 17.2 & 16.4 & 0.52 & 0.15 & 0.00 & 0.14 \\
\hline Heart, \% & $0.57^{\mathrm{a}}$ & $0.54^{\mathbf{b}}$ & $0.45^{\mathbf{b}}$ & 0.57 & 0.64 & 0.60 & 0.01 & 0.05 & 0.00 & 0.03 \\
\hline $\begin{array}{l}\text { Abdominal } \\
\text { fat pad, } \mathrm{g}\end{array}$ & 32.8 & 32.8 & 30.8 & 48.4 & 48.0 & 48.4 & 1.92 & 0.948 & 0.00 & 0.924 \\
\hline $\begin{array}{l}\text { Abdominal } \\
\text { fat pad, } \%\end{array}$ & 1.33 & 1.34 & 1.27 & 1.72 & 1.77 & 1.77 & 0.06 & 0.94 & 0.00 & 0.88 \\
\hline
\end{tabular}

Table 4-Effects of Tribulus terrestris (TT) extract on digestive parts of broiler chicks

Çizelge 4-Etlik civcivlerde TT ekstraktının sindirim organlarına etkileri

\begin{tabular}{|c|c|c|c|c|c|}
\hline Parameters & Control & $180 T T$ & $360 T T$ & SEM & $P$ values \\
\hline Crop, $\mathrm{g}$ & 8.0 & 8.7 & 6.5 & 0.45 & 0.13 \\
\hline Crop, \% & 0.30 & 0.34 & 0.25 & 0.02 & 0.45 \\
\hline Proventriculus, $\mathrm{g}$ & 10.0 & 7.3 & 7.5 & 0.89 & 0.42 \\
\hline Proventriculus, \% & 0.38 & 0.28 & 0.29 & 0.03 & 0.45 \\
\hline Gizzard, g & 43.0 & 42.0 & 40.0 & 1.61 & 0.76 \\
\hline Gizzard, \% & 1.63 & 1.63 & 1.56 & 0.06 & 0.88 \\
\hline Pancreas, $\mathrm{g}$ & 6.5 & 6.7 & 6.5 & 0.28 & 0.97 \\
\hline Pancreas, $\%$ & 0.25 & 0.26 & 0.25 & 0.01 & 0.92 \\
\hline Intestine, $\mathrm{g}$ & $68.0^{\mathrm{a}}$ & $56.7^{\mathbf{b}}$ & $57.0^{\mathbf{b}}$ & 1.89 & 0.002 \\
\hline Intestine, $\%$ & $2.58^{\mathrm{a}}$ & $2.20^{\mathrm{b}}$ & $2.23^{\mathrm{b}}$ & 0.06 & 0.01 \\
\hline Duodenum, $\mathrm{g}$ & $14.5^{\mathrm{a}}$ & $13.3^{\mathrm{ab}}$ & $10.5^{b}$ & 0.73 & 0.03 \\
\hline Duodenum, \% & $0.55^{\mathrm{a}}$ & $0.52^{\mathrm{ab}}$ & $0.41^{\mathrm{b}}$ & 0.49 & 0.05 \\
\hline Ileum + jejunum & $53.5^{\mathrm{a}}$ & $43.3^{\mathbf{b}}$ & $46.5^{b}$ & 1.51 & 0.003 \\
\hline Ileum + jejunum, $\%$ & $2.03^{\mathrm{a}}$ & $1.68^{\mathbf{b}}$ & $1.82^{\mathrm{b}}$ & 0.05 & 0.006 \\
\hline Ceca, $\mathrm{g}$ & 8.0 & 8.0 & 7.5 & 0.32 & 0.79 \\
\hline Ceca, \% & 0.30 & 0.31 & 0.29 & 0.01 & 0.87 \\
\hline Colon, $\mathrm{g}$ & 4.5 & 6.7 & 6.0 & 0.45 & 0.13 \\
\hline Colon, $\%$ & 0.17 & 0.26 & 0.23 & 0.02 & 0.11 \\
\hline Empty gut, g & $141.5^{\mathrm{a}}$ & $129.3^{\mathrm{ab}}$ & $124.5^{\mathbf{b}}$ & 3.22 & 0.048 \\
\hline Empty gut, \% & 5.37 & 5.03 & 4.87 & 0.11 & 0.13 \\
\hline
\end{tabular}


as control birds did. This might be a result of increased digestive enzymes or changed hormonal status of treatment birds due to the chemical content of TT. Also, the decreasing effect of TT on intestine weight can be attributed to (1) TT might have decreased lipid accretion and (2) decreased the injuries of epithelial tissue of intestine since Sati et al (2009) found out that TT extract decreased injuries in aorta endothelial and blood lipid levels in rabbit.

\section{Conclusion}

The present study showed that Tribulus terrestris had no effect on growth or muscle building, suggesting that TT extract do not work in birds as do in human subjects, more likely, due to the physiological difference between human and animal species.

\section{Acknowledgement}

The authors are thankful to TUBITAK and Mustafa Kemal University for supporting our project VHAG-2109.

\section{References}

Adimoelja A \& Adaikan P G (1997). Protodioscin from herbal plant Tribulus terrestris L. improves male sexual functions possibly via DHEA. International Journal of Impotence Research 9(1): S64

Brown G A, Vukovich M D, Martini E R, Kohut M L, Franke W D, Jackson, D A \& King D S (2001). Effects of androstenedione-herbal supplementation on serum sex hormone concentrations in 30-59 years old men. International Journal for Vitamin and Nutrition Research 71(5): 293-301

Çek Ş, Turan F \& Atik E (2007). Masculinization of convict cichlid (Cichlasoma nigrofasciatum) by immersion in Tribulus terrestris extract. Aquaculture International 15(2): 109-119

Combarieu E D, Fuzzati N, Lovati M \& Mercali E (2003). Furostanol saponins from Tribulus terrestris. Fitoterapia 74(6): 583-591

Conrad J, Dinchev D, Klaiber I, Mika S, Kostova I \& Kraus W (2004). A novel furostanol saponin from Tribulus terrestris of Bulgarian origin. Fitoterapia 75(2): 117-122

Dimitrov M, Georgiev P \& Vitanov S (1987). Use of tribestan on rams with sexual disorders. Veterinarno Meditsinski Nauki 24(5): 102-110

Duru M (2005). Yohimbe Bark (pausinystalia yohimbe) ve demir dikeni (Tribulus terrestris) ekstratlarının etlik civcivlerde büyüme performansı ve vücut bileşimi üzerine olası anabolik etkilerinin araştırılması. Yüksek lisans tezi, Mustafa Kemal Üniversitesi Fen Bilimleri Enstitüsü (Basılmamış), Hatay

Ganzera M, Bedir E \& Khan I A (2001). Determination of steroidal saponins in Tribulus terrestris by reversed-phase high-performance liquid chromatography and evaporative light scattering detection. Journal of Pharmaceutical Sciences 90(11): $1752-1758$

Gauthaman K, Adaikan P G, Prasad R N V, Goh V H H \& Ng S C (2000). Changes in hormonal parameters secondary to intravenous administration of Tribulus terrestris extract in primates. International Journal of Impotence Research 12(S2): 6

Gauthaman K, Adaikan P G \& Prasad R N V (2002). Aphrodisiac properties of Tribulus terrestris extract (Protodioscin) in normal and castrated rats. Life Science 71(12): 1385-1396

Gauthaman K \& Adaikan P G (2008). The hormonal effects of Tribulus terrestris and its role in the management of male erectile dysfunction - an evaluation using primates, rabbit and rat. Phytomedicine 15(1): 44-54

Adaikan P G, Gauthaman K, Prasad R N \& Ng S C (2000). Proerectile pharmacological effects of Tribulus terrestris on the rabbit corpus cavernosum. Annals of the Academy of Medicine Singapore 29(1): 22-26

Geyer H, Mareck-Engelke U, Reinhart U, Thevis M \& Schänzer W (2000). Positive doping cases with norandrosterone after application of contaminated Nutritional supplements. Deutsche Zeitschrift für Sportmedizin 51(11): 378-382

Kostova I \& Dinchev D (2005). Saponins in Tribulus terrestris-chemistry and bioactivity. Phytochemistry Reviews 4(2-3): 111-137

Kostova I, Dinchev D, Rentsch G H, Dimitrov V \& Ivanova A (2002). Two new sulphated furostanol saponins from Tribulus terrestris. Zeitschrift für Naturforschung 57(1-2): 33-38

Kreider R B (2001). Tribulus Terrestris Update. Muscular Development 38(10): 3

Pandian T J \& Sheela S G (1995). Hormonal induction of sex-reversal in fish. Aquaculture 138(1): 1-22 
Sahin A \& Forbes J M (1997). Dehydroepiandrosterone (DHEA) for modulation of the effect of corticosterone on diet selection and body components in broiler chickens. British Poultry Science 38: 53-54

Sati L, Cayli S, Tuncer A T, Yaymaci B, Altug T \& Demir R (2009). Kolestrolden zengin diyetle beslenmiş yeni zelanda tavşanlarında Tribulus terrestris ekstraktının aort endoteli üzerine koruyucu etkisi. 19. Ulusal Elektron Mikroskopi Kongresi 105, 22-25 Haziran, Trabzon, Türkiye

Street C, Antonio A \& Cudlipp D (1996). Androgen use by athletes: a reevaluation of the health risks. Canadian Journal of Applied Physiology 21(6): 421440
Sun W, Gao J, Tu G, Guo Z \& Zhang Y (2002). A new steroidal saponin from Tribulus terrestris Linn. Natural Product Letters 16(4): 243-247

Wang Y, Ohtani K, Kasai R \& Yamasaki K (1997). Steroidal saponins from fruits of Tribulus terrestris. Phytochemistry 45(4): 811-817

Wu G, Jiang F, Jiang S, Zhu D, Wu H \& Jiang S (1996). Steroidal glycosides from Tribulus terrestris. Phytochemistry 42(6): 1677-1681

Wu T S, Shi L S \& Kuo S C (1999). Alkaloids and other constituents from Tribulus terrestris. Phytochemistry 50(8): 1411-1415 